\title{
Information Literacy As An Implementation Of Tabayun Concept In Islam
}

\author{
Muhamad Riza \\ Universitas Islam Negeri Sunan Gunung Djati Bandung \\ E-mail: muhamadriza@uinsgd.ac.id
}

\begin{abstract}
The concept of Information Literacy (IL) may be recognized as a recent concept. Along with the growth of information technology, other literacy such as Digital Literacy emerged as consequences of unfamiliarity with the new-emerging technology. However, Information Literacy is as relevant as the technology itself particularly todays. In an era in which users are flooded with information, and most of information they receive are frequently irrelevant to what they need. In addition, with the abundance of information available on the internet, most of the time the information they get are invalid. The example of fake news circulating on social media as we may have heard many times is because people are not able to evaluate information they receive. This paper explores the way in which the concept of Information Literacy is related to and found on the concept of Tabayun in Islam. The carefulness of evaluating information as the prophet Muhammad used to do when he received information that possibly be disinformation is one of the scopes in Information Literacy. The paper use library research method in discribing the key concepts of Information Literacy and Tabayyun of Information in Islam.the findings of the paper explores ways in which information can be evaluated through saveral methods and theories in order to get better, valid and reliable information.
\end{abstract}

Keywords: Information Literacy, Tabayyun, Disinformation, Information Technology.

\begin{abstract}
Abstrak
Konsep Literasi Informasi bisa dianggap sebagai konsep yang baru. Bersamaan dengan berkembangnya Teknologi Informasi, berbagai kemamapuan literasi yang lain seperti Literasi Digital muncul seiring dengan ketidaktahuan terhadap teknologi yang baru muncul. Namun, kemampuan Literasi Informasi menjadi sangat relevan dengan perkembangan teknologi khusunya sekarang. Di era dimana para pengguna informasi dibanjiri dengan informasi, dan sebagian besar informasi yang diperoleh tidak relevan dengan yang dibutuhkannya. Sebagai tambahan dengan banyaknya informasi yang
\end{abstract}

Tik Ilmeu : Jurnal Ilmu Perpustakaan dan Informasi

IAIN Curup | p-issn: 2580-3654; e-issn:2580-3662

DOI: $10.29240 /$ tik.v5i2.2866 
terdapat di internet, sebagian informasi yang mereka daatkan tidak valid. Contohnya adalah berkembangnya berita bohong di internet dan sosial media dikarenakan pengguna informasi tidak bisa mengevaluasi informasi yang mereka dapatkan. Artikel ini mengeksplorasi konsep literasi informasi merupakan implementasi dari konsep Tabayyun di Islam. Kehati-hatian dalam mengevaluasi informasi seperti yang Nabi Muhammad lakukan ketika mendapatkan informasi untuk menghindarkan dari misinformasi merupakan salah satu cakupan dari Literasi Informasi. Metode penelitian yang digunakan adalah metode penelitian kajian pustaka dimana penulis menggambarkan beberapa konsep kunci dari literasi informasi dan konsep tabayyun informasi dalam Islam. Artikel ini menemukan bahwa ada beberapa metode dan teori dalam mengevaluasi informasi untuk mendapatkan informasi yang lebih baik, lebih valid dan lebih dapat dipercaya .

Kata Kunci: Literasi Informasi, Tabayyun, Disinformasi, Teknologi Informasi.

\section{A. INTRODUCTION}

The rapid growth of information technology has always been seen as a good sign where information can be accessed by everyone and everywhere even in the remote places. That statement is not further from the truth. We have witnessed, since the inception of the internet and its rapid expansion all over the globe, the need for information is growing from politics to healthrelated information, from academic-related information to entertainment.

Almost half of the people on this planet are connected to the internet. In 2015, data from International Telecomunication Union(BBC, 2015.) shows that 3.2 billion people were online and almost 2 billions of them were from developing countries, including Indonesia. This can be seen as a good sign in which accessibility to the internet is no longer monopolized by developed or first-world countries. This is the promised that the internet has achieved where everyone has access to information regarding his/her race, religion or countries. Internet enables everyone to find his/her desired information and can be the ones to inform others as well.

However, with the huge amount of availability of information on the internet, sometimes it is hard to find the relevant information, or sometimes the valid ones. Since everyone can post everything on the internet, it is hard to find reliable information. Moreover, since the growth of social media such as Facebook or Twitter, everyone can post anything they wish without having to check whether the information they share are valid. This leads to major 
issue in the last couple of years where people post invalid information or disinformation.

In the last couple of years, we may have heard several people were arrested for publishing what appeared to be fake news or hoaxes on social media. This occurrence repeatedly happened not just once but many times. Furthermore, sometimes those who share fake news or hoaxes on Social Media are educated people and have at least bachelor's degree. The blame goes beyond individual and into educational system in this country.

The need to have a systematic understanding of how to use internet is what Information Literacy all about. Although the concept was introduced in 1974 by Paul Zukcowski (Eisenberg et al., 2004)) long before the birth of internet, the concept is still relevant today's age in what Toffler (1981) regards as Information society. Being able to find, evaluate and use the information for practical purposes is the main them of IL. This includes how to evaluate information that possibly be invalid and may cause harm to people.

Long before the birth of Internet as well as Zuckowsky coined the term Information Literacy, in seventh century Islam, the need to evaluate information for its validity had already been practiced. The concept called Tabayyun in which someone has to research or investigate the received information so it does not harm people under any circumstances. This first revealed in Al-Quran Surah Al Hujarat verse six. In it Allah orders Prophet Muhamad specifically and his followers to varify the information. This due to the wars they underwent and in those wars, disinformation or giving false information deliberately is one of ways to win wars.

The latest examples would be the amount of misinformation circulating the internet about covid-19 virus which initiated in late 2019. The misinformation or disinformation about the virus which came from unreliable sources or sometimes media outlets had led people into confusion or, to an extreme level, fear about the virus since the information related to the virus were inconsistent, contradictory and sometimes exaggerated.

The misinformation about the spread of the virus or mortality rate caused by the virus was massive in the beginning of the pandemic. It had an impact to people who attempted to find reliable information about the virus to better protect themselves from the virus. Moreover, as the pandemic comes to more than a year after it first spread in Wuhan, the amount of misinformation and disinformation about the virus still circulating on the internet. 
This paper attempts to integrate the two-seemingly distinct concepts yet they both have many things in common. Information Literacy is basically a recent concept as a result of rapid growth in Information Technology. Meanwhile, Tabayun is a seven-century concept in Islam which was practiced in early Islam by Prophet Muhammad. The two concepts in this paper attempt to tackle a major issue in information age, namely disinformation.

The first part of the paper explores the problem of the current age deals with. From information explosion to disinformation and how those problems occurred in the first place. Later, it explores ways in which Information Literacy has to offer not only as a response to the rapid growth of Information Technology but also to the problems that follow. In addition, the concept of tabayyun as well will be briefly discussed and how the concept could play a role in today's society regarding the acquisition of information.

The second part of the writing will discuss the definition and the scope of Information literacy. That includes the ten criteria of Information Literate by Doyle (1994), the scope and other literacies that relate to Information Literacy as well as how the literacy is crucial in the internet age as today. The second part as well will disscuss the concept of tabayyun. From its inception to how back in the day was used to evaluate information and how those information could be profitable in terms of financial or knowledge.

This paper uses philosophical approach in which it explores the concept of Information Literacy and also the concept of Tabayyun in Islam. The paper then compares the commonalities between two concepts and how those concepts can be used to tackle disinformation or misinformation on the Internet. The paper, as well, shares the techniques of evaluating information from American Library Association standard for Information Literacy and as well from the Quran in which several verses of the Quran discuss the need to investigate information for its validity.

\section{Literature Review}

The studies on the relation between information literacy and misinformation or disinformation on the internet is somewhat rare in terms of its publication. Information literacy always refers to people or customers in search of their needed information, especially in library. The term "information literacy" itself is a library and Information Science terminology that the stereotype would refer to information needs in library context. On the other hand, the term disinformation or misinformation, especially on the internet, is often associated with digital literacy. 
Khan and Idris (2019) study on how misinformation are spread in the conext of information literacy in social media. they conducted survey to wether people have the ability to recognize false information on social media and the ability to acknowledge the behaviour of sharing information without verification. The research found that the ability to verify information is based on saveral factors such as by income and education level, information and verification skills and also the the way in which people's attitude toward verifying those information.

Leawdowsky's (2019) approach from the perspective of cognitive science about misinformation in politics also touches the ability of citizenary in information literacy. The study focusses on how the behaviour of political figure (e.g. Donald Trump) and his supporters sometimes accussed of mainstream media as a fake news when it comes to arguments against them. The term misinformation or fake news at the time of Donlad Trump took the office was popular terminologies not only information the president felt against him but also information that came from him.

Jaeger and Taylor (2021) as well study misinformation from he perspective of information literacy. The study as Lewandowsky's, focus on the ever-growing misinformation on social media in terms of political and socio-culural phenomena. The study proposes the lifelong learning through information literacy and the significant of library in teaching or informing information literacy skills in tackling disinformation and misinformation on the internet.

When it comes to Islam, Parrot (2018) also has an approach on misinformation in Islam using information literacy skills. He reviews historically and on the basis of theology about the importance of verifying information before disseminating them. He also proposes to be lifelong learning as it is the purpose of information literacy in order to pursue the information and knowledge that available on the internet.

\section{B. RESULTS AND DISSCUSSION}

The concept of information literacy was first introduced by Paul Zurkowski in 1974 as a response to the growth of Information resources in the field of Library and Information institutions. The various sources of information available that time prompted information specialists to figure out how users could deal with the various sources of information available without being overwhelmed. 
There are various definitions of Information literacy from various experts. However, those definitions mostly refer to similar things. One of the definition by Burchinal(Eisenberg et al., 2004) referring to the person who is information literate is the one who possess skills in which know how to locate and then use the information for various reason but ultimately for problem-solving and decision-making as effective and efficient as possible.

One complete definition or requirement for someone who is information literate was given by Doyle (1994) where he formulates ten requirements for someone who possesses such a high literacy in information. The below requirement are Doyle's and extracted from Eisenberg, et al(Eisenberg et al., 2004)

The first requirement is someone who is information literate is being able to identify the exact information needed for decision-making processes. This could apply both in private corporation or in public institution or any individual case. For instance, in a company, those who are able to use the exact and complete information for decision making process which leads to profitable income can be called information literates.

The second requirement Doyle argues that information literates need to possess is being able to acknowledge the need for information What it means by that is that someone who is information literate is relying their decision-making on information not by guessing or "hunch". the third requirement for Information literates is someone who understands information needs.

The next one is to be able to know the various sources of information. An information literate does not rely only on one source of information. In today's context, sources of information are abundant. Most people are only use internet as their primary source, however an information literate able to use many sources of information besides internet such as books and archival records in a library for example so the it will make the information more abundant yet relevant.

The next one is being able to use or develop strategies in their search for information. Most users are not able to find the right information they need because lack of knowledge in finding those information. Information literates have to be able to find the needed information by applying their knowledge on how to find them. Not only finding information but also finding them effectively and efficiently. The later requirement is quite similar to the forth requirement. Doyle Argues that Information Literates have to 
access information on computer and other technologies. But Doyle present his idea before computer and internet were the main things.

The later requirement that Doyle argues is that an information literate has to evaluate his/her information. After finding the desired information, evaluating those information are crucial task as well. In case the information found are invalid or obsolete or maybe irrelevant. One can argue that the internet is abundant with information that everyone needs. However not all information on the internet is valid. Some of them are invalid or maybe just a personal opinion. Furthermore, an information literate has the ability and the knowledge to distinguish whether the information are valid and relevant.

The eight criteria that information literate needs to possess is to organize the acquired information for practical purposes. After information acquired and evaluated, information literate needs to organize the information in certain ways so that the information can be used effectively and efficiently. For example, a librarian organizes information sources such as books or other sources to make library users easy to retrieve those information. Or other example in private company, the information specialist will organize the information so when the company needs the information it will be easily retrieved.

The second to last requirement of information literate is to be able combine the information that has been received into prior knowledge of the user. Which means that the information acquired is an addition or an update to the existing knowledge. The last requirement of an information literates is being able to use the information critically and also use them in problem solving. This is the last phase of the acquisition of information how to use those information for practical reason and moreover for problem solving.

\section{The concept of Tabayun in Islam}

There are various definition of the word Tabayyun itself. However the term first appeared in Alquran,Surah Al Hujarat verse six:

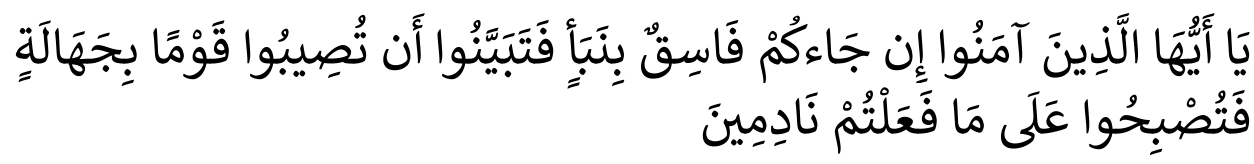


O you who have believed, if there comes to you a disobedient one with information, investigate, lest you harm a people out of ignorance and become, over what you have done, regretful.

The verse describes those who receive information to be cautiously investigate the information for their validity. Because as what the verse above describes, sharing or giving invalid information may cause harm over people. So the verse asks people to do Tabayyun or in other words, research or investigate the information.

One of the famous cases of the harm of disinformation is the tragedy or more precise the genocide in Rwanda in the early 1990s where over 800.000 people were killed. Disinformation may not be the primary reasons the genocide happened but the propaganda and constant disinformation that the media did before the tragedy made it worse (Pottier, 2002). That is exactly Allah warns in the Surah Al-Hujarat Verse Six that the worst case scenario over misleading people over information people are harmed, or in the case of Rwanda, people were brutally killed.

There are many other verses in Quran that asks Moslems to seek and investigate every information they receive. The other example are from Surah An-Nisa Verse 83:

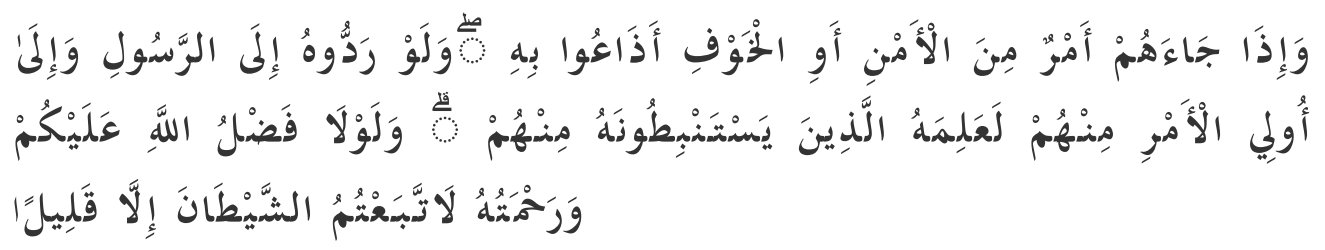

And when there comes to them information about [public] security or fear, they spread it around. But if they had referred it back to the Messenger or to those of authority among them, then the ones who [can] draw correct conclusions from it would have known about it. And if not for the favor of Allah upon you and His mercy, you would have followed Satan, except for a few.

In this verse, Allah again warns about information that could possibly be invalid either it is intentional or by accident. The urgency to do Tabayyun or research or an investigation on the information just like what the verse tells us to do is to avoid us from harm that may come form misinformation or disinformation. 
Prophet Muhammad understood the danger impact of misinformation or where someone received information without being validated. in one example how prophet Muhammad ordered his followers to validate the information for their authenticity was when one of the groups of his follower called Bani Al-Mustalaqah was rumored to refuse to collect Zakat and they also rumored to be hostile toward the informant and ready to go to war.

However, after Prophet Muhamad sent another informant by the name of Khalid Al-walid the rumor was never valid in the first place. On contrary Bani Al-Mustalaqah, was always welcomed to the prophet's order in collecting the Zakat and never been hostile or in any form of refusal toward prophet's policy(Walidah, 2017). This event was where prophet Muhammad order his follower to evaluate information for their validity or tabayyun in order to avoid the dangerous effects that come from misinformation.

Effendi explores four methods of Tabayyun that has been applied since the dawn of Islam. Namely: Tajribi, Bayani, Burhani, and Irfani Method. Tajribi Method as described by Ibrahim(2016) is the method of seeking information based on logic or rationality which further can be tasted in real-world experiments. This method is similar to scientific method which has been prevalent in academic and scientific communities for centuries

The Bayani method of inquiry is classical method in Islam in which it seeks to find the meaning in the revelation either in the Qur'an or in The sunnah. The method requires a person to read, comprehend, and analyze either the text or the context (Ibrahim, 2016) . The method could be applied in assessing information where users are unsure about the validity or the authenticity of information by analyzing the text thoroughly and the context of information such as the source of information.

The third method that could be applied in the attempt of Tabayyun of information is Burhani Method. Ibrahim (2016) argues that Burhani method seeks to investigate every phenomenon based on logic and in a systematic way. The method shares a common ground with Information literacy process in which one is called an information literate is the one who identifies, evaluates and uses information in systematic way.

The last method of inquiry in Islam that has been prevalent for centuries for Islamic schoolars is Irfani. Irfani method of inquiry is a method that focuses on individual relation to God. This method as well uses individual instinct and intuition in investigating phenomenon(Rangkuti, 2016). Intuition and instinct can be used to investigate information for their 
validity since human race, from the dawn of time, has been using intuition and instict acquired from their experience.

\section{Tabayun And Information Literacy In Solving Disinformation On The Internet}

The similarity of concept in both Information Literacy and Tabayyun is that people ought to seek investigation of the information they receive. Although evaluating information is just one step in information literacy among other step of requirements of an information literate, but it is one the most crucial ones. Along with Tabayyun or investigating of received information, users of technology or social media can be better to select and evaluate information they share on particularly social media.

There are steps to mitigate or even diminish the spread of disinformation or misinformation on internet particularly on social media. The steps are taken from American Library Association Information Literacy Standard for Higher Education(Information Literacy Competency Standards for Higher Education, 2000). The steps are from outcome of standard three in which it focuses on how so-called information literate have to be able to critically evaluate the received information.

The first step to recognize the validity of information is to closely examine and compare sources of information on a given subject or topic. If, for instance, an information is circulating around social media within which a user is not fully sure of the validity of that information, user can fact-check the information on other various sources. This includes do a Google searches and see if any major news outlets are covering the information as well. The writer is fully aware that even major outlets have their own political bias, however they are bound by Journalistic ethics and law unlike small or every anonymous who post information or news online.

The second step as the Standards for Competency of Information Literacy from ALA above suggests is to critically analyze the written structures or arguments to recognize logical fallacy in the writing. This requires critical thinking skills in analyzing the discourse of the text. This can be done by recognizing whether those who share the information possibly pushing their personal or political narrative and aim to have personal gain.

The third step is to recognize whether information contain prejudice against certain groups or intended to be misleading. This step of recognizing disinformation can utilize the first and second step where people can factcheck their information from various sources and as well analyze the 
information critically for biases. These steps in recognizing fake news or disinformation are crucial in the current age filled with hoaxes or fake news circulating primarily on social media.

The standards from ALA above is similar to concept in evaluating information. Although Tabayyun does not give a detail explanation as with Information Literacy, it gives an overarching theme of finding validity or doing investigation on the validity of information. One example of Tabayyun concept in Surah Annisa, as cited above, is to refer to the information authority. If someone is not sure of the validity of information, he/ she can have a second opinion from an expert or someone who has knowledge on that particular topic or subject.

There are, however, other methods in evaluating information on the internet. One of which comes from Kohang and Weiss( 2003) they propose three stages of information evaluation before disseminating information for hoaxes prevention. They are: 1) Information identification, 2) Information Analysis, and 3) Information organization.

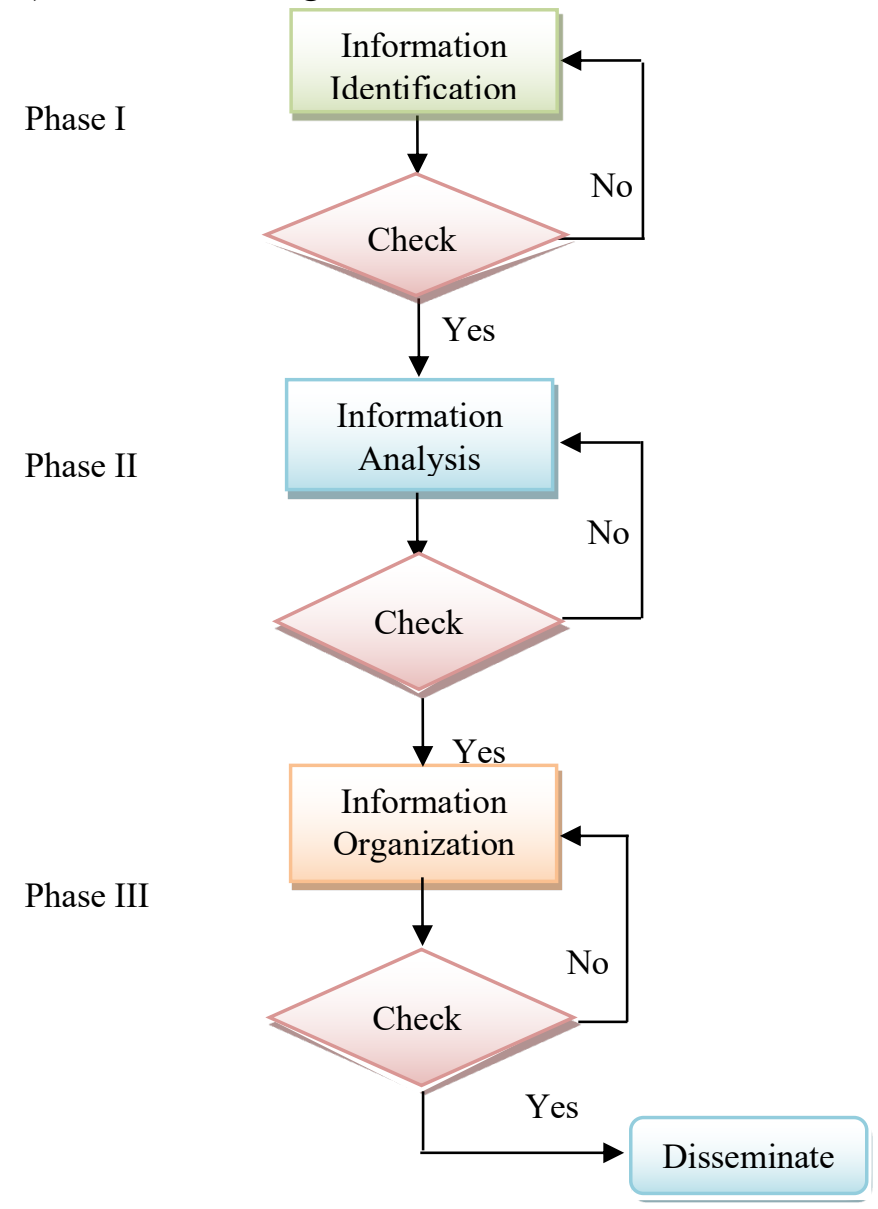




\section{Diagram 1: Misinformation Prevention}

Framework from Kohang and Weiss (2003: 114)

Information identification phase of which Kohang and weiss propose deals with identifying the necessary information for user's needs. This phase deals with what the users are trying to accomplish with the information. That includes identifying relevant information. The massive amount of information available on the internet on one subject could mislead users from receiving what they are initially trying to find.

The second phase from Kohang and Weiss(2003) framework for misinformation prevention is information analysis. As Kohang and weiss themselves argue that this phase is the most crucial phase from the other two. This phase deals with how users can analyize the information for their accuracy, relevancy and comprehensiveness. In this phase, the users as well need to analyze information that tend to be bias or opinion rather than fact. Users as well need to check the source of information as it might come from unreliable sources or the ones that possibly be bias or disseminating inconsistent information. The last phase from Kohang and Weiss framework for misinformation prevention is information organization. This phase deals with how users organize the information that have been identified and analyzed for dissemination. This includes disseminating information for the right audiences. Also the information that are about to be disseminated have to be easily accessible or found by users.

In addition, once the phases are completed and users or information creators have disseminated information, the need for ongoing evaluation of those information is still necessary. As the amount of information are flooded the internet that information that have been disseminated could be obsolete in the next hours or so.

\section{CONCLUSION}

This paper gives a glimpse of how scientific and revelation-based approaches can be used to tackle a contemporary issue in the internet age, namely disinformation. The issue is more prevalent now than ever particularly since the inception of social media such as Facebook, Twitter, and others. The issue of disinformation on social media is not merely an issue of erasing or banning social media to mitigate the problems. Because most of the world are living in a democratic countries, using social media can be seen as an option, and an authority such as government is no under circumstances has a right to ban them. 
Islam, since its inception, has a method of verifying information in order to mitigate the effects from misinformation. Tabayyun has been practiced since centuries from Islamic scholars as a form of "Jihad" in finding useful information. The method relates to the term Information Literacy since both have the same purpose which includes to find and evaluate the needed information in every aspect of life.

\section{BIBLIOGRAPHY}

BBC. (n.d.). Internet used by 3.2 billion people in 2015 - BBC News.

Retrieved September 9, 2021, from

https://www.bbc.com/news/technology-32884867

Doyle, C. (1994). Information literacy in an information society : a concept for the information age. 80 .

Eisenberg, M. B., Lowe, C. A., Spitzer, K. L., \& Spitzer, K. L. (2004). Information literacy : essential skills for the information age. 408.

Ibrahim, D. (2016). Metodologi Penelitian dalam Kajian Islam (Suatu Upaya Iktisyaf Metode-Metode Muslim Klasik). Intizar, 20(2), 247-266. https://doi.org/10.19109/intizar.v20i2.432

Information Literacy Competency Standards for Higher Education. (n.d.). Retrieved September 9, 2021, from http://www.ala.org/acrl/standards/informationliteracycompetency.

Jaeger, P. T., \& Taylor, N. G. (2021). Arsenals of Lifelong Information Literacy: Educating Users to Navigate Political and Current Events Information in World of Ever-Evolving Misinformation. Https://Doi.Org/10.1086/711632, 91(1), 19-31. https://doi.org/10.1086/711632

Khan, M. L., \& Idris, I. K. (2019). Recognise misinformation and verify before sharing: a reasoned action and information literacy perspective. Https://Doi.Org/10.1080/0144929X.2019.1578828, 38(12), 1194-1212. https://doi.org/10.1080/0144929X.2019.1578828

Koohang, A., \& Weiss, E. (2003). Misinformation: Toward Creating a Prevention Framework.

Lewandowsky, S. (2019). The 'Post-Truth' World, Misinformation, and Information Literacy: a Perspective From Cognitive Science. In Informed Societies (pp. 69-88). Facet. https://doi.org/10.29085/9781783303922.006 
Parrott, J. (2018). Finding Truth in the Age of Misinformation: Information Literacy in Islam. Yaqeen Institute for Islamic Research.

Rangkuti, C. (2016). Sekolah Tinggi Agama Islam As-Sunnah Deli Serdang Implementasi Metode Bayani, Burhani, Tajribi Dan 'Irfani Dalam Studi Filsafat Pendidikan Islam. Jurnal Waraqat, I(2), $1-12$.

Walidah, I. Al. (2017). Tabayyun di Era Generasi Millenial. Jurnal Living Hadis, 2(2), 317-344. https://doi.org/10.14421/livinghadis.2017.1359 